\title{
Response of Pot Marigold to Different Applied Levels of Humic Acid
}

\author{
Sohail Ahmad ${ }^{1}$, Junaid Khan ${ }^{1}$ and Aftab Jamal ${ }^{*}$ \\ ${ }^{1}$ Department of Agricultural Sciences, University of Haripur, Pakistan \\ ${ }^{2}$ Department of Soil and Environmental Sciences, The University of Agriculture Peshawar, \\ Pakistan
}

aftabses98@gmail.com

\section{Keywords: Humic acid, Marigold, Haripur, Flowering}

\begin{abstract}
A research study was conducted to determine the effects of different doses of humic acid (HA) on growth and yield of marigold at Horticulture Nursery Univ. of Haripur, Khyber Pakhtunkhwa, during the spring season. The experiment was laid under Completely Randomized Design with 5 replications and 8 pots per replication were used. The treatments of humic acids were $(\mathrm{T} 1=$ control, $\mathrm{T} 2=250, \mathrm{~T} 3=750, \mathrm{~T} 4=1000 \mathrm{ml} / \mathrm{L}$ respectively). Significant differences were found in treated flowers. The higher values were noted in leaf length, flower length, number of flowers per plants and flower width. The higher values of leaf length $(7.46 \mathrm{~cm})$, number of flowers per plant (2.9), flowers width $(9.92 \mathrm{~cm})$ and flowers length $(20.18 \mathrm{~cm})$ were found by the application of $750 \mathrm{ml} / \mathrm{L}$ of HA. However the maximum number of flowers per plant was (5), flower width $(1.48 \mathrm{~cm})$ and flower length $(3.28 \mathrm{~cm})$ were found with the application of $1000 \mathrm{ml} / \mathrm{L} \mathrm{HA}$.
\end{abstract}

\section{Introduction}

Calendula (Calendula officinalis L.) is one of the major ornamental and medicinal plant it known as pot marigold. It belongs to family Asteraceae. The name of Calendula officinalis L. comes from Latin word (Calend) meaning the first day of each month because this plant has a long flowering period and move in the solar radiation [1].

Origin of calendula is west Asia and Mediterranean. Many times the calendula was considered as an ornamental plant before its medicinal properties known. The plant was first cultivated as a herbal medicine in Europe in the $17^{\text {th }}$ century and now there is in Germany, Czech Republic, Slovakia, Austria and Switzer Land, Hungary and recently in Egypt and Syria. Calendula also grows in Palestine, Iraq, Saudi Arabia, Egypt, Libya, Tunisia, Algeria, Morocco, Canary Islands, southern Spain Turkmenistan, Afghanistan, Pakistan and Kashmir [2].

Vegetative part of calendula plant is covered with fine hairs. Lower leaves are paddle while upper leaves are smaller and pointed. Composite flowers are yellow to orange and born on multibranched stalk. Flowers are heterogeneous. Seeds are grey or light brown in color, vary in shape and decrease in size towards the center of the head.

Cultivation of calendula is stimulated by the pharmaceutical industry as well as by developing manufacturing of cosmetics. The pharmaceutical industry uses either florets or completes composite flowers of calendula which are deep orange in color and have a specific smell and bitter taste. Calendula plant material contains a wide range of active substances, including essential oil, triterpene saponins, flavonoids, carotenoids, saponins, polyacetylenes, sterols, carbohydrates, vitamin $\mathrm{C}$, mucilages and minerals, e.g. manganese, which makes the plant an important source of preparations with therapeutic effects used in pharmacy and medicine [3, 4].

Calendula is used in soups, stews and salads. It is used in different products e.g. toothpaste, shampoo, skin care products. Seeds of calendula are used as oil seed. Its seed contains 40-60\% oil. This oil is used in cosmetics, paint and coating. Calendula oil reduces inflammation. It is used in wound healing and as antiseptic. It is also better for skin diseases [5].

Use of humic acid and bio-fertilizers is proposed to modify soil texture, soil structure integrity, aeration and increase nutrient absorption. Humic acid is a commercial product containing abundant nutrients improves soil fertility and increase the availability of nutrients to plants and thus it influences plant growth and yield [6]. 
It was found [7] that humic acid containing compounds in Hoagland solution, increased nitrogen uptake and improved overall yield in cucumber (Cucumis sativus L). In was reported [8] that the use of humic acid and chemical fertilizers improves nutrient absorption in lettuce (Lactuca sativa).

Keeping in mind the importance of humic acid the present study was launched to evaluate the influence of different doses of Humic acid on growth, yield and flowering of (Calendula officinalis).

\section{Materials and Methods}

\section{Experimental site}

The pot experiment was conducted in Calendula (Calendula officinalis L.) was carried out in Horticulture Nursery, The University of Haripur located at 33 $43^{\prime} 59.99^{\prime \prime} \mathrm{N}$ and $72^{\circ} 34^{\prime} 59.99^{\prime \prime} \mathrm{E}$ of Khyber Pakhtunkhwa, Pakistan at elevation of 610 meters above the sea level. In each pot 1 Calendula plant was sowed and four treatments were tested.

\section{Media preparation and Cultural practices}

Pots were filled with light soil about $(2 \mathrm{~kg}$ ), classified as good rye complex soil, developed from heavy loamy sand and these pots were subjected to humic acid treatments $(0,250,750$, $1000 \mathrm{ml} \mathrm{L}^{-1}$ ) on the basis of complete randomized design with 5 replications. Soil moisture was maintained at around of water capacity. Pot marigold inflorescences were harvested in the full bloom phase, every 5 days ( 5 to 7 times during a growing season.) Before the harvest, biometric quantities of the plants were taken, including the number of flowers plant ${ }^{-1}$, Size of flowers, number of leaves plant ${ }^{-1}$ and length of leaves were determined.

\section{Treatments}

$$
\begin{aligned}
& \mathrm{T}_{1}=\text { Control } \\
& \mathrm{T}_{2}=250 \mathrm{ml} \mathrm{L}^{-1} \\
& \mathrm{~T}_{3}=750 \mathrm{ml} \mathrm{L}^{-1} \\
& \mathrm{~T}_{4}=1000 \mathrm{ml} \mathrm{L}^{-1}
\end{aligned}
$$

\section{Data collection}

The following growth and developmental parameters were measured during the experiment:

1. Number of leaves plant ${ }^{-1}$

2. Leaf length $(\mathrm{cm})$

3. Number of flowers plant ${ }^{-1}$

4. Flower width $(\mathrm{cm})$

5. Flower Length $(\mathrm{cm})$

\section{Statistical analysis}

The data collected were analyzed statistically according to the procedure given by Jandel Scientific (1991) using Statistic, 2000 package and Least Significant Difference (LSD) test were used for any significant difference among the treatments as suggested [9].

\section{Results and Discussion}

\section{Effect of different doses of humic acid on number leaves plant}

The effect of different doses of humic acid on the total number of leaves was found nonsignificant (Table 1). The maximum number of leaves (16.3) was found in treatment $\mathrm{T} 2\left(250 \mathrm{ml} \mathrm{L}^{-1}\right)$ 
while the minimum number of leaves was found (11.7) in treatment T4 $\left(1000 \mathrm{ml} \mathrm{L}^{-1}\right)$. Humic acid applied at the rate of $250 \mathrm{ml} \mathrm{L}^{-1}$ gave better results than $1000 \mathrm{ml} \mathrm{L}^{-1}$ of humic acid. The similar results were reported by [10] concluded that the humic acid in $250 \mathrm{ml} \mathrm{L}^{-1}$ concentrations, increased the number of marigold leaves which could be due to positive mineral effects and the hormonal activity of humic acid on vegetative growth.

\section{Effect of Humic acid levels on leaf length}

The observation revealed that the application of humic acid at different doses had a significant effect on the leaf length of calendula flower (Table 1). The result showed that the maximum leaf length $(7.46 \mathrm{~cm})$ was achieved by calendula flower when humic acid was applied at the rate of $750 \mathrm{ml} \mathrm{L}^{-1}$. However, decreased in leaf length was found $(3.54 \mathrm{~cm})$ in control. The similar finding was related to [11] who investigated the effect of humic acid on leaf area and length and concluded that HA improves the physiological processes within the plant.

\section{Effect of Humic acid levels on the number of flowers plant}

The results indicated that the application of humic acid at different levels had a significant effect on the number of flowers plant ${ }^{-1}$. The analysis of variance showed that the maximum numbers of flower (2.9) were observed when humic acid was applied at the rate of $750 \mathrm{ml} \mathrm{L}^{-1}$. While the minimum numbers of flower $(0.80)$ were recorded in control treatment (Table 1). [12] Also concluded that calendula plant has more flower by humic acid as foliar application.

\section{Effect of Humic acid levels on flower width}

According to the analysis of variance, the levels of humic acid on flower size had a significant effect (Table 1). The maximum size of flower $(9.92 \mathrm{~cm})$ was recorded when humic acid was applied at the rate of $750 \mathrm{ml} \mathrm{L}^{-1}$ and the minimum was recorded $(1.4 \mathrm{~cm})$ at the rate of $1000 \mathrm{ml} \mathrm{L}^{-1}$.[13] reported that humic acid increase number of flower and width of flower with the presence of GA3 (plant growth regulator).

\section{Effect of Humic acid levels on flower length}

The analysis of variance revealed that the recorded data was highly significant (Table 1). The result showed that maximum length of flower $(20.18 \mathrm{~cm})$ was recorded when humic acid was applied at the rate of $750 \mathrm{ml} \mathrm{L}^{-1}$ and the minimum was recorded $(3.28 \mathrm{~cm})$ at the rate of $1000 \mathrm{ml} \mathrm{L}^{-1}$. However, humic acid at the rate of $750 \mathrm{ml} \mathrm{L}^{-1}$ gave a better result as compare to apply at the rate of $1000 \mathrm{ml} / \mathrm{L}$ humic acid level. These result matched with $[14,15]$ recorded that application of humic acid to African marigold plants at $100 \mathrm{ppm}$ concentration envisaged the maximum plant height, spread of plant and flower yield when compared with other treatments.

Table 1. Effects of Humic acid doses on growth and flowering of calendula.

\begin{tabular}{|l|l|l|l|l|l|}
\hline $\begin{array}{l}\text { Foliar doses of } \\
\text { Humic acid }\end{array}$ & $\begin{array}{l}\text { Number } \\
\text { of leaves } \\
\text { plant }^{-1}\end{array}$ & $\begin{array}{l}\text { Leaf length } \\
\text { (cm) }\end{array}$ & $\begin{array}{l}\text { Number of } \\
\text { flowers plant }\end{array}$ & $\begin{array}{l}\text { Flower } \\
\text { width }(\mathbf{c m})\end{array}$ & $\begin{array}{l}\text { Flower length } \\
\text { (cm) }\end{array}$ \\
\hline Control & $14.6 \mathrm{AB}$ & $3.54 \mathrm{C}$ & $0.8 \mathrm{BC}$ & $1.68 \mathrm{~B}$ & $6.54 \mathrm{BC}$ \\
\hline HA $250 \mathrm{ml} \mathrm{L}^{-1}$ & $16.3 \mathrm{~A}$ & $4.38 \mathrm{BC}$ & $2.3 \mathrm{AB}$ & $6.6 \mathrm{~A}$ & $13.28 \mathrm{~B}$ \\
\hline HA $750 \mathrm{ml} \mathrm{L}^{-1}$ & $13.8 \mathrm{AB}$ & $7.46 \mathrm{~A}$ & $2.9 \mathrm{~A}$ & $9.92 \mathrm{~A}$ & $20.18 \mathrm{~A}$ \\
\hline HA $1000 \mathrm{ml} \mathrm{L}^{-1}$ & $11.7 \mathrm{~B}$ & $4.92 \mathrm{~B}$ & $0.3 \mathrm{C}$ & $1.48 \mathrm{~B}$ & $3.28 \mathrm{C}$ \\
\hline Mean & 14.1 & 5.0 & 1.5 & 4.9 & 10.7 \\
\hline LSD $\leq 0.05$ & 4.5717 & 1.2308 & 1.6376 & 4.1993 & 6.8889 \\
\hline
\end{tabular}

Means with different letter ( $s$ ) in columns are significantly different at $\mathrm{p}<0.05$. 


\section{Conclusions}

It was concluded from the study that lower dose of $\mathrm{HA}$ at $250 \mathrm{ml} \mathrm{L}^{-1}$ produced the maximum number of leaves plant ${ }^{-1}$ of calendula, however, leaf length, flower length, flower size by width and number of flowers plant ${ }^{-1}$ were significantly improved with the application of HA at $750 \mathrm{ml} \mathrm{L}^{-1}$. Hence $\mathrm{HA}$ at $750 \mathrm{ml} \mathrm{L}^{-1}$ was considered the best dose for calendula plant in the prevailing soil and environmental conditions.

\section{Conflict of Interest}

The authors declare that there is no conflict of interest.

\section{References}

[1]K. Dinda, LE. Craker, Growers Guide to Medicinal Plants, HSMP Press, Amherst, 1998, pp. 35 37.

[2]A. Zolfaghari et al., Identification of medicinal plants and indigenous knowledge of local people Arasbaran, J. Med. Arum. Plants. 28(3) (2013) 534-550.

[3]S. Bielski, B. Szwejkowska, Effect of fertilization on the development and yields of pot marigold (Calendula officinalis L.), Herba Polonica. 59(2) (2013) 5-12.

[4]I. Dedio, J. Kozłowski, R. Załęcki, Calendula - cultivation and use in medicinal therapies, Wiadomości Zielarskie. 5 (1986) 1-2.

[5]C. Schiller, D. Schiller, The aromatherapy encyclopedia: a concise guide to over 385 plant oils, Basic Health Publications, Inc., 2008.

[6]H. Ayas, F. Gulser, The effect of sulfur and humic acid on yield components and macronutrient contents of spinach, J. Biol. Sci. 5(6) (2005) 801-804.

[7]B.S. Rauthan, M. Schnitzer, Effects of a soil fulvic acid on the growth and nutrient content of cucumber (Cucumis sativus) plants, Plant Soil. 63(3) (1981) 491-495.

[8]M.K. Cimrin, I. Yilmaz, Humic acid applications to lettuce do not improve yield but do improve phosphorus availability, Acta Agriculturae Scandinavica, Section B- Plant Soil Science. 55(1) (2005) 58-63.

[9]R.G.D. Steel, J.H. Torie, Principles and procedures of Statistics, 2nd ed., McGraw Hill Book Co., New York, USA, 1980.

[10]E. Mohammadipour et al., Effect of humic acid on yield and quality of marigold (Calendula officinalis L.), Annals of Biological Research. 3(11) (2012) 5095-5098.

[11]M.A. El-Khateeb, A. El-Leithy, B. Aljemaa, Effect of mycorrhizal fungi inoculation and humic acid on vegetative growth and chemical composition of Acacia saligna Labill. seedlings under different irrigation intervals, Journal of Horticultural Science \& Ornamental Plants. 3(3) (2011) 283-289.

[12]B. Sani, Foliar application of humic acid on plant height in canola, APCBEE Procedia. 8 (2014) 82-86.

[13]N.A. Azzaz, E.A. Hassan, F.A. El Emarey, Physiological, anatomical, and biochemical studies on pot marigold (Calendula officinalis L.) plants. African Crop Science. 8 (2007) 1727-1738.

[14]H.M. Sunitha et al., Effect of pinching and growth regulators on plant growth, flowering and seed yield in African marigold (Tagetes erecta Linn.), Journal of Ornamental Horticulture. 10(2) (2007) 91-95.

[15]M. Bihari et al., Variability studies in canna genotypes, Journal of Ornamental Horticulture. 12(3) (2009) 217-221. 